\title{
Ovarian cycle in Devario aequipinnatus with emphasis on oogenesis
}

\author{
Laíza Maria de Jesus-Silva ${ }^{2,3}$, Pricila Viana de Oliveira ${ }^{2,3}$, Cristiéle da Silva Ribeiro ${ }^{4}$, \\ Alexandre Ninhaus-Silveira ${ }^{3}$ and Rosicleire Veríssimo-Silveira ${ }^{1,3}$ \\ FEIS/UNESP, Campus de Ilha Solteira, São Paulo, Brasil
}

Date submitted: 11.04.2017. Date revised: 31.01.2018. Date accepted: 18.02.2018

\section{Summary}

This study aimed to understand how germ cell development occurs in females of Devario aequipinnatus, by morphologically describing oogenesis and the reproductive phases. Sexually mature females of D. aequipinnatus $(n=70)$ were obtained from commercial fisheries and delivered to the Laboratório de Ictiologia Neotropical, UNESP, Ilha Solteira, SP, Brazil. The ovaries were removed, fragmented and fixed following the usual techniques for light microscopy. The stages of ovarian development in D. aequipinnatus begin with the oogonia, which proliferate into new cells or differentiate into prophasic oocytes that, at the end of this process, form the ovarian follicle and end folliculogenesis. In the previtellogenic stage, the oocytes were characterized mainly by the gradual loss of basophilia and an increase in oocyte diameter. Vitellogenesis was marked mainly by the incorporation of yolk granules. Mature oocytes were defined by their migration from the nucleus to the micropyle. Postovulatory follicles and atresic oocytes were also observed. The reproductive phases were classified as: immature, early and final developing, spawning capable, regressing and regenerating. Therefore, the development of an understanding of cell modifications that occurs up to oogenesis is a basic step that is essential for the description of the reproductive biology of D. aequipinnatus, given the lack of information about the reproductive aspects of this species.

Keywords: Danio, Fish, Germ cells, Morphology, Reproduction

\section{Introduction}

The family Cyprinidae is the most diverse of the freshwater fishes (Nelson, 1994; Fu et al., 2003),

\footnotetext{
${ }^{1}$ All correspondence to: Rosicleire Veríssimo-Silveira. Departamento de Biologia e Zootecnia, FEIS/UNESP - Universidade Estadual Paulista 'Júlio de Mesquita Filho', Rua Monção, 226, Zona Norte, Ilha Solteira, São Paulo, 15385-000, Brasil. Tel: +55 (18) 37431935. Fax: +55 (18) 37422140. E-mail: rosiverissimo@bio.feis.unesp.br

${ }^{2}$ Programa de Pós-Graduação em Ciência e Tecnologia Animal - FEIS/UNESP - Universidade Estadual Paulista, Campus de Ilha Solteira, São Paulo, Brasil.

${ }^{3}$ Laboratório de Ictiologia Neotropical - L.I.NEO., Departamento de Biologia e Zootecnia, FEIS/UNESP Universidade Estadual Paulista 'Júlio de Mesquita Filho', Rua Monção, 226 - Zona Norte, Ilha Solteira, São Paulo, 15385-000, Brasil.

${ }^{4}$ Departamento de Biologia e Zootecnia, FEIS/UNESP Universidade Estadual Paulista 'Júlio de Mesquita Filho', Rua Monção, 226, Zona Norte, Ilha Solteira, São Paulo, 15385-000, Brasil.
}

with around 3002 species (Eschmeyer \& Fong, 2017) distributed almost worldwide except for Australia and Antarctica (Mayden, 1991). Within the family there are several important species with culinary, aquarium and biological uses, for example the common carp (Cyprinus carpio), goldfish (Carassius auratus) and zebrafish (Danio rerio) (Nelson, 2006); the latter is an excellent biological model used in genetics, embryology (Nelson, 2006), toxicology (Lele \& Krone, 1996; Arunachalam et al., 2013), molecular biology, neuroscience and other areas of biomedical research (Arunachalam et al., 2013).

Like the other cyprinids, Devario aequipinnatus has many advantages, such as low maintenance costs, low space requirements and a rapid reproductive cycle (Lele \& Krone, 1996), and it is also an important biological model for scientific research. However, knowledge of the reproductive biology of this species is scarce, especially regarding gonadal aspects.

The characterization of germ cells in their different stages as well as their distribution and frequency in the ovaries would allow us to infer the processes involved 

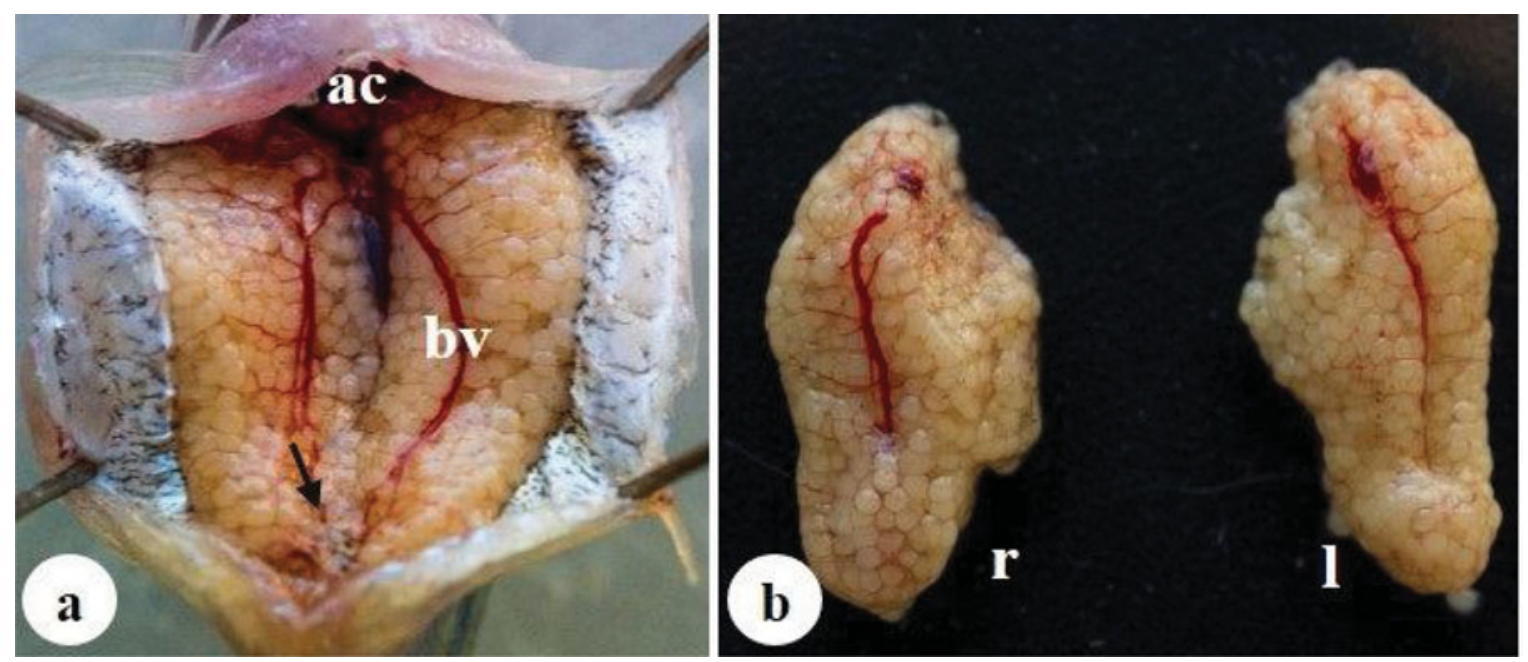

Figure 1 Ovaries in D. aequipinnatus. (a) Ovaries inside the abdominal cavity (ac). (b) Ovaries: right (r) and left (l). Abbreviations: bv: blood vessels. Arrow: ovaries fused in caudal portion.

in ovarian development and type of spawn of the species (Lima et al., 1991). Histology is an important tool to acquire knowledge in reproductive biology (West, 1990). According to Selman \& Wallace (1989), the growth of these cells occurs differently in various groups of fish, so an understanding of the development of the gametogenesis process will provide information on maturation and fertilization.

Thus, the present study aimed to characterize the ovarian cycle of $D$. aequipinnatus, describing morphologically oogenesis and the reproductive phases.

\section{Materials and Methods}

Sexually mature females of D. aequipinnatus ( $n=$ 70) were obtained from commercial fisheries in the Uberlândia region, MG, Brazil, then forwarded to the Neotropical Ichthyology Laboratory - LINEO, UNESP, Ilha Solteira, SP, Brazil where they remained for 30 days for acclimation. The animals were fed daily with Super Red commercial feed composed of 38\% crude protein and $16 \%$ mineral material. The animals were kept in a $12 \mathrm{~h}$ light:12 $\mathrm{h}$ dark (12L:12D) photoperiod and the aquarium was cleaned daily with 10 to $20 \%$ water exchange. As a procedure to maintain water temperature and quality, chillers, aerators, thermostats and filters were used.

The animals were collected and euthanized with an alcohol solution containing benzocaine $(0.2 \mathrm{~g} / \mathrm{l})$ according to the protocol approved by the Commission on Ethics in the Use of Animals (11/2013/CEUAFEIS/UNESP). After anaesthesia, the animals had their mass $(\mathrm{g})$, total and standard length $(\mathrm{cm})$ measured. Posteriorly, an incision was made in the ventral region of the animal, exposing the abdominal cavity for removal of the ovaries.

The ovaries were collected and sectioned transversely in the medial region. The fragments were fixed in a solution of $4 \%$ paraformaldehyde and $2 \%$ glutaraldehyde in Sorensen phosphate buffer, $\mathrm{pH} 7.4$ for $24 \mathrm{~h}$. After fixation, samples were dehydrated in alcohol solutions with increasing concentrations, embedded in glycol-methacrylate historesin (Technovit $7100)$, sectioned at $3.0 \mu \mathrm{m}$ on a microtome equipped with a glass blade (LEICA RM 2245) and stained with haematoxylin and eosin. For measurement of diameter of oocytes and photoprocessing, an optical microscope Zeiss equipped with camera AXIOCAM-MRc5 was utilized.

The classification of development of phases based on macroscopic and microscopic characteristics of ovaries and germ cells was performed according BrownPeterson et al. (2011).

\section{Results}

Devario aequipinnatus ovaries are paired organs fused in the caudal portion and irrigated by blood vessels located in the celomatic cavity, surrounded by conjunctive tissue (tunica albuginea) (Fig. 1a, $b$ ). The ovaries are formed of somatic and germ cells. The somatic cells are initially named the prefollicle (Fig. 2a, b); only after the formation of the ovarian follicle are they classified as follicle cells (Fig. 2c). The stages of oocyte development begin with the oogonia, the precursor cells of all the oogenesis process. In general, oogonia can proliferate into new cells (Fig. $2 a$ ) or differentiate into prophasic oocytes (Fig. $2 b$ ) that, at the end of this process, form 


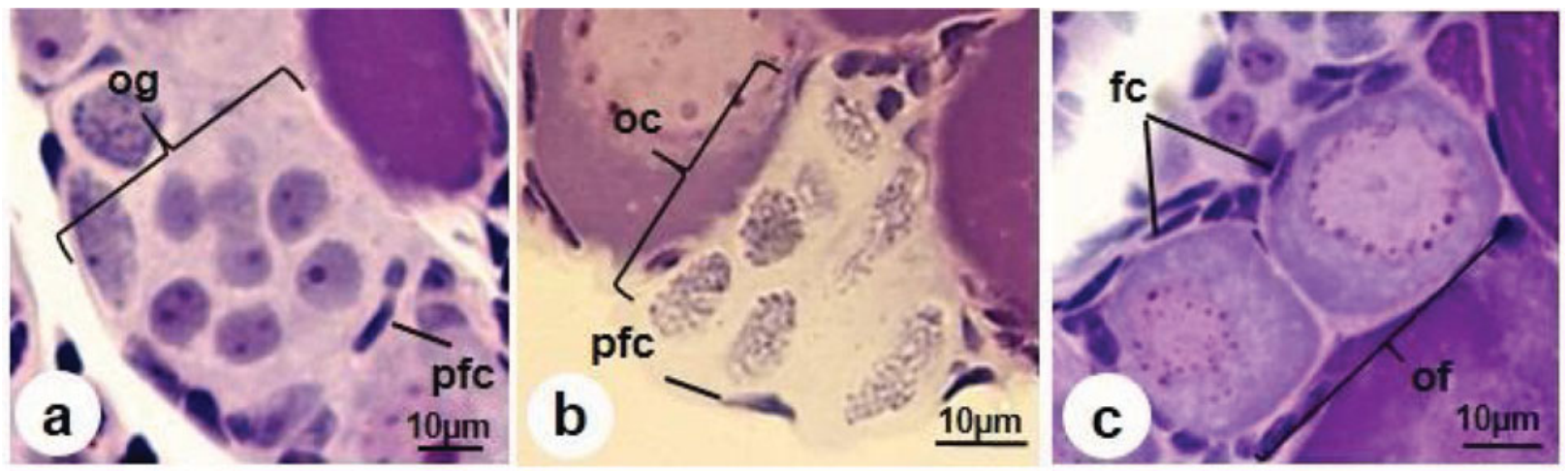

Figure 2 Folliculogenesis in D. aequipinnatus. (a) Cyst of oogonia. (b) Prophasic oocyte. (c) Formation of the ovarian follicle. Abbreviations: oc: oocyte; of: ovarian follicle; og: oogonia; fc: follicle cells; pfc: prefollicle cells. Stain: haematoxylin and eosin.

the ovarian follicle (Fig. 2c) to end folliculogenesis. The germ cells undergo different stages of development until the liberation of oocytes into the ovarian lumen, i.e. ovulation.

\section{Stages of germ cells}

At the end of the folliculogenesis stage, the germ cell begins primary growth or the previtellogenic stage, secondary growth or the vitellogenic stage and final maturation. Postovulatory follicles and atresic oocytes were also found.

\section{Primary growth}

Initial previtellogenic oocytes. These cells have a clear basophilic cytoplasm due to the intense proliferation of cellular organelles, a rounded nucleus with slight coloration and several nucleoli in the periphery. The follicle cells are squamous with a flattened nucleolus, scarce and separated from each other (Fig. 3a, b). Oocytes are still small when compared with the final development stage, with a diameter of $118.6 \mu \mathrm{m} \pm 20.5$ $\mu \mathrm{m}$, and can be observed in the Balbiani corpuscle that resemble fissures (Fig. 3b).

Final previtellogenic oocytes. As cellular development advances, the cytoplasm becomes less basophilic, with several nucleoli (Fig. 3c). In this stage, there is the appearance of many cortical alveoli, located along the cytoplasm (Fig. 3c). There is also the appearance of the zona radiata, which is a striated and acellular layer with pink coloration measuring $4.1 \mu \mathrm{m}$ (Fig. 3d). Many squamous follicle cells are observed, but these are different from those seen in the previous step, as they are closer to each other (Fig. 3d). These oocytes measure around $246.4 \mu \mathrm{m} \pm 42.2 \mu \mathrm{m}$ in diameter and are also observed in the theca cell layer (Fig. 3b).

\section{Secondary growth}

Initial vitellogenic oocytes. The cells increase in size according to stage, measuring around $421.1 \pm 63.3 \mu \mathrm{m}$ in diameter. The deposition of the yolk granules continues to occupy the center of the cytoplasm and, at the same time, the cortical alveoli are numerous, migrating to the cellular periphery (Fig. 3e). The follicle cells remain squamous and are closer to each other; the zona radiata measures $4.5 \mu \mathrm{m}$ (Fig. 3f).

Final vitellogenic oocytes. In this stage, the nucleus is central, yolk granules fill the cytoplasm and the cortical alveoli are in the oocyte periphery (Fig. $3 g$ ). Oocytes increase in size (around 590.4 $\pm 108.3 \mu \mathrm{m}$ in diameter) and nucleoli that were found in the periphery begin to occupy all the nucleus (Fig. $3 g$ ). The zona radiata thickens to $4.67 \mu \mathrm{m}$ (Fig. $3 h$ ) and follicle cells remain squamous (Fig. 3h).

\section{Final maturation}

Mature oocytes. This is the last stage of development in which the cells can attain a maximum length of $721.1 \pm 59.8 \mu \mathrm{m}$ and width of $586.2 \pm 57.2 \mu \mathrm{m}$. The yolk granules occupy all of the cytoplasm, the cortical alveoli remain in the periphery (Fig. $3 i, j$ ) and the zona radiata attains its maximum thickness of $6.81 \mu \mathrm{m}$ (Fig. 3j). At this time, the follicle cells become cuboidal (Fig. 3j). This stage is marked by the migration of the germinal vesicle (nucleus) towards the micropyle (Fig. 3i, k).

Atresic oocytes. These oocytes become flaccid and can be found at any time during the reproductive cycle. They are characterized by disorganization of the cytoplasm, in which liquefaction of yolk granules and cortical alveoli occurs, and the zona radiata becomes thinner. The follicles cells are hypertrophic and have a thicker aspect (Fig. 3l). These oocytes will later be reabsorbed.

Postovulatory follicle. These follicles are formed by several follicle cells, theca cells and a basement membrane. After the release of oocytes in the ovulation process, these layers remain in the ovigerous lamellae, forming one layer because the ovarian lumen becomes irregular with blood vessels around it (Fig. 3l). 


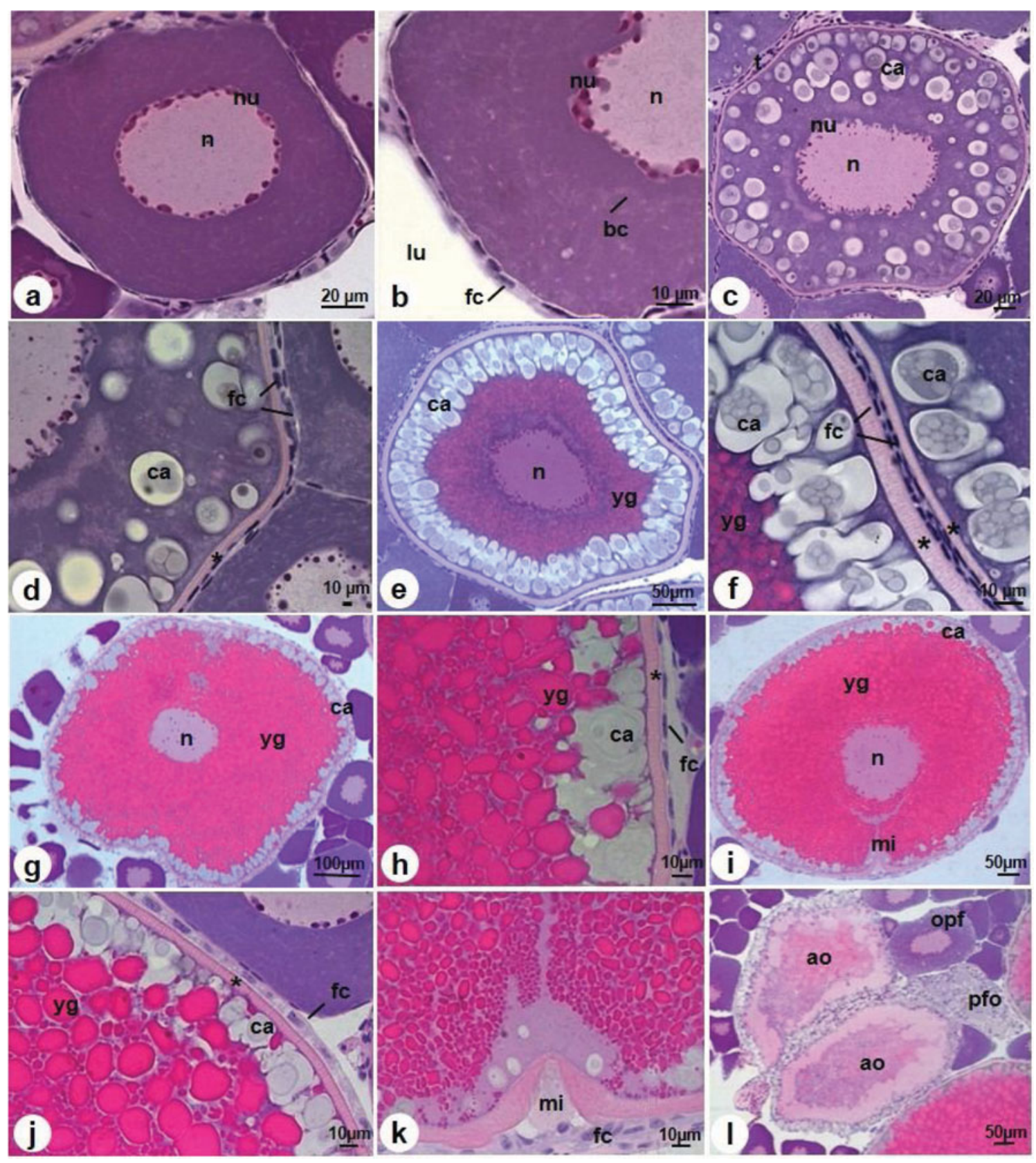

Figure 3 Oogenesis in D. aequipinnatus. (a) Initial previtellogenic oocyte with nucleoli (nu) in the periphery. (b) Squamous follicle cells (fc). (c) Final previtellogenic oocytes with cortical alveoli (ca) in cytoplasm. (d) Comparison of follicle cells between final previtellogenic and initial previtellogenic oocytes. (e) Initial vitellogenic oocyte with cortical alveoli in the periphery (ca) and yolk granules centralized. $(f)$ Comparison of follicle cells and zona radiata between initial vitellogenic and final previtellogenic oocytes. $(g)$ Final vitellogenic oocytes with the central nucleus (n) and accumulation of yolk granules (yg). (h) Squamous follicle cells. (i) Mature oocyte with migration of nucleolus (n) toward micropyle (mi). (j) Cuboidal follicle cells. ( $k$ ) Detail of micropyle. (l) Atresic oocytes (ao) and postovulatory follicle (pfo). Abbreviations: bc: Balbiani bodies; opf: final previtellogenic oocyte; lu: ovarian lumen; t: theca. Asterisk: zona radiata. Stain: haematoxylin and eosin.

\section{Reproductive phases}

The morphology of the ovaries undergoes modifications throughout the development of germ cells, and thus oocytes in the previtellogenic, vitellogenic, mature, atresic and postovulatory follicle stages can be found. In this way, the reproductive phases are classified by germinal epithelium alterations associated with ovarian development, similar to the modifications that occur in the ovigerous lamellae. 


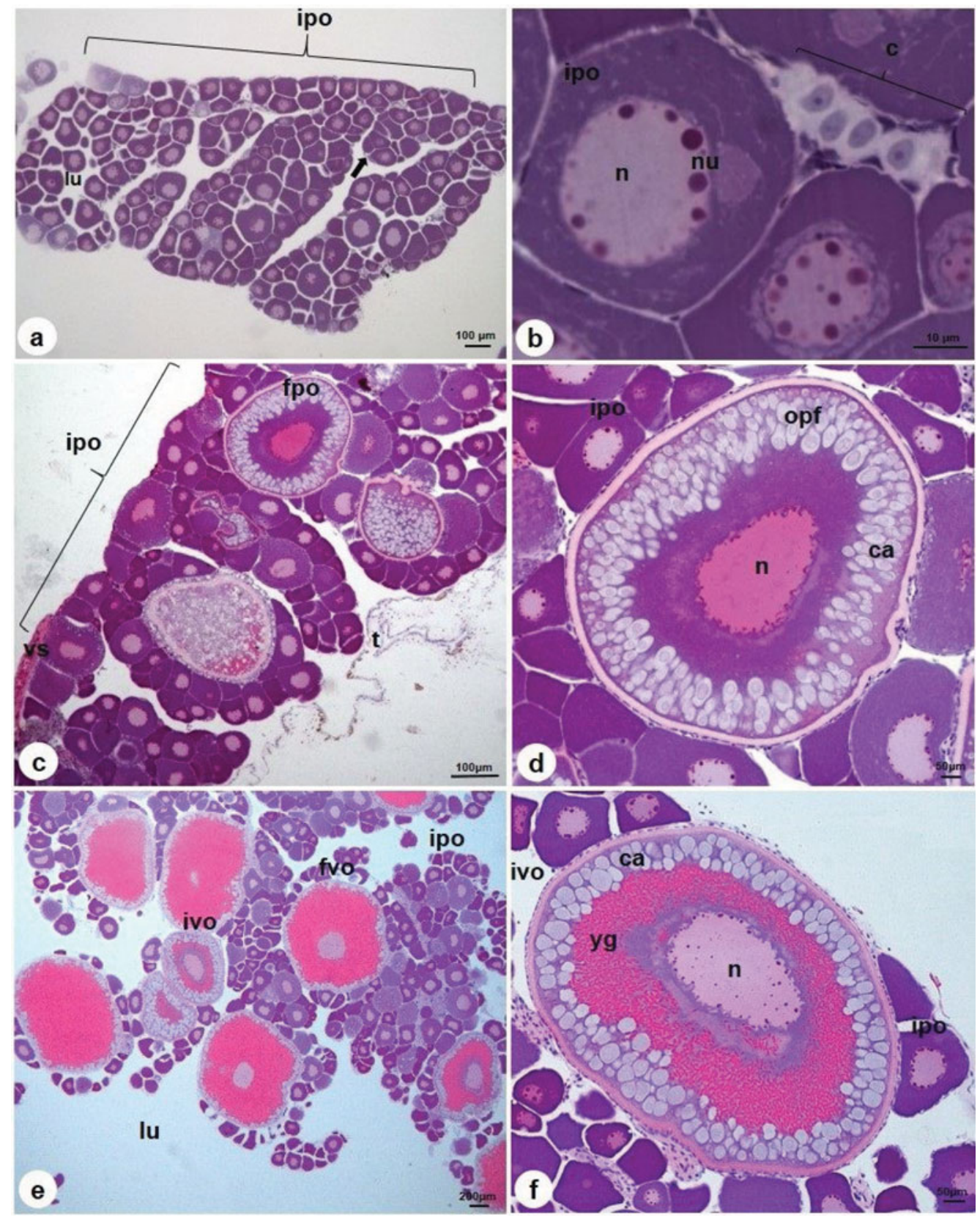

Figure 4 Ovaries in D. aequipinnatus in different reproductive phases. $(a, b)$ Ovaries in immature phase with only previtellogenic oocytes (ipo) with organization of ovigerous lamellae (thick arrow). (b) Detail of initial previtellogenic oocytes (ipo) with nuclei (nu) in the nucleus periphery (n) and cysts of oogonia (c). (c-f) Ovaries in development phase. (c, $d$ ) Subphase of initial development. Ovaries with initial previtellogenic oocytes (ipo) and final previtellogenic oocytes (fpo). (e, $f$ ) Subphase of final development. Ovaries with initial previtellogenic oocytes (ipo); initial vitellogenic oocytes (ivo). Abbreviations: ca: cortical alveoli; fvo: final vitellogenic oocytes; lu: ovarian lumen; t: tunica albuginea; yg: yolk granules. Stain: haematoxylin and eosin.

\section{Immature}

The ovaries are thick, and ovigerous lamellae are in formation with little space between them (Fig. 4a). This phase is characterized by the predominance of initial previtellogenic oocytes (Fig. 4a), but oogonia in cysts are also observed (Fig. 4b). Few oogonia and prophasic oocytes are seen in this phase.

\section{Developing}

For a more detailed understanding of this phase, we subdivided it into two subphases.

Early developing subphase. These ovaries are developing and have only primary growth oocytes, i.e. initial and final previtellogenic (Fig. 4a). This phase is marked by the appearance of cortical alveoli in the final previtellogenic oocytes (Fig. 4b). 
Final developing subphase. In this subphase, secondary growth with initial vitellogenic oocytes is observed as well as final vitellogenic oocytes (Fig. 4e). Previtellogenic oocytes are also present (Fig. 4e). This phase is marked by the incorporation of yolk granules in the initial vitellogenic oocytes (Fig. 4f).

\section{Spawning capable}

In this phase, the ovary reaches it maximal development and occupies all space in the ovigerous lamellae. Mature oocytes are predominant with eccentric nucleus migrating to the periphery (Fig. $5 b$ ) but other types of oocytes and structures are also observed, such as initial and final previtellogenic oocytes (Fig. 5a), postovulatory follicles and atresic oocytes, which can be identified in any phase of development of ovary (Fig. 5b).

\section{Regressing}

In this phase, the ovaries become flaccid and there is more space between the ovigerous lamellae due the release of mature oocytes (Fig. $5 c$ ). The ovaries have previtellogenic oocytes, but mainly there are many atresic oocytes (Fig. $5 c$ ) and postovulatory follicles (Fig. $5 d$ ). This phase finishes the final reproductive cycle.

\section{Regenerating}

In this phase, the ovaries undergo restructuring of ovigerous lamellae (Fig. 5e) and produce a large quantity of nests and cysts with germ cells (Fig. $5 f$ ). Mitotic proliferation of oogonia occurs along with the formation of prophasic oocytes, which renew the reproductive cycle, and only initial previtellogenic oocytes predominate (Fig. 5e).

\section{Discussion}

In teleosts, the formation of ovigerous lamellae in the ovaries supports the development of germ cells. These ovigerous lamellae emit projections towards the stroma and present distinct morphological characteristics according to the stage of oocyte development (Ganeco et al., 2001). These aspects of ovaries have been described for several groups, including Brycon orbignyanus (Ganeco et al., 2001), Acestrorhynchus pantaneiro (Rodrigues et al., 2005) and Pimelodus maculatus (Amorim, 2007). In D. aequipinnatus, the ovigerous lamellae also undergo modifications, becoming more developed along the oocyte growth.

Folliculogenesis begins with the proliferation of the oogonia, and the differentiation of the oocytes occurs later (Grier, 2000, 2012; Andrade et al., 2001; Grier et al., 2007; Mazzoni et al., 2010). For D. aequipinnatus these modifications are observed and follow the pattern of other teleost orders, specifically Siluriformes and Labriformes (Quagio-Grassiotto et al., 2011; SantosSilva et al., 2015).

In D. aequipinnatus, oogenesis was classified according to the morphological alterations of the cells, considering the nuclear, nucleolus, and cytoplasmic. Thus, these criteria can also be used for the classification of oogenesis stages in other species, such as Puntius conchonius, Ctenopharyngodon idella and Danio rerio (Çek et al., 2001; Glasser et al., 2003; Çakici \& Üçüncü, 2007). This way, the identification of primary, secondary and maturation growth stages in D. aequipinnatus is similar to other cyprinids.

During the previtellogenic stage, the zona radiata and the cortical alveoli are important structures that support ovarian development (Selman \& Wallace, 1989; Patiño \& Sullivan, 2002). These structures were observed in D. aequipinnatus and other representatives of Cypriniformes [e.g., Danio rerio (Yön et al., 2008, Connolly et al., 2014) and Cyprinus carpio (Shabanipour \& Hossayni, 2010)], in which the zona radiata appears during the final previtellogenic stage, concomitantly with the cortical alveoli, which becomes thicker and more developed with advanced ovarian growth. The zona radiata plays an important role in the transport of substances for yolk synthesis (Celius \& Walther, 1998), such as proteins and lipids that are essential in the processes of vitellogenesis, maturation and hatching (Çakici \& Üçüncü, 2007).

The cortical alveoli are composed of proteins and carbohydrates and are responsible for the induration of the zona radiata (Tyler \& Sumpter, 1996), and are a barrier to polyspermia (Wallace \& Selman, 1981; Ohta et al., 1990; Rodrigues et al. 2005) during fertilization. This is corroborated in D. aequipinnatus, in which these alveoli occupy the peripheral region of the cytoplasm and a greater increase occurs in its proportion as oogenesis progresses, as has been described for Serrasalmus maculatus (Quagio-Grassiotto et al., 2014).

The incorporation of the yolk granules into the cytoplasm occurs at the beginning of vitellogenesis such as Brycon orthotaenia (Gonçalves et al., 2006); Metynnis maculatus, Megalancistrus parananus, Cichla kelberi, Satanoperca pappaterra (Martins et al., 2010) and Laetacara araguaiae (Santos-Silva et al., 2015). Whereas in D. aequipinnatus, this incorporation occurs only at the end of previtellogenesis. Thus, granule proteins are an important energy reserve for the embryo and sustain its development (Rodrigues et al., 2005; Amorim, 2007).

Resumption of the meiotic process initiates the maturation stage (Abascal \& Medina, 2005), which is completed with fertilization (Quagio-Grassiotto et al., 2013). In this stage, the germ vesicle (nucleus) migrates towards the micropyle region (Honji et al., 2006; 

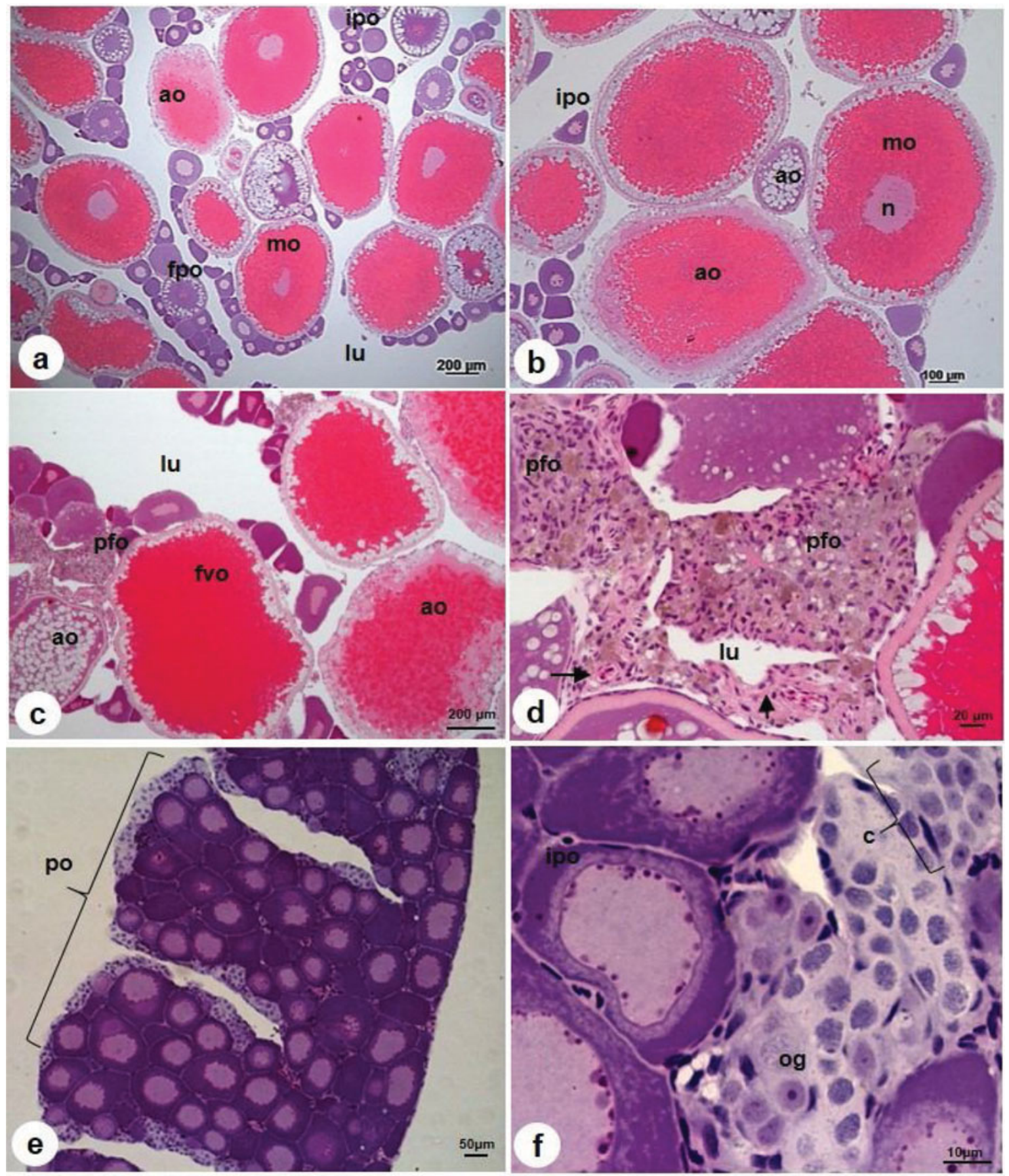

Figure 5 Ovaries in $D$. aequipinnatus in different reproductive phases. $(a, b)$ Ovaries in spawning capable phase with mature oocytes with eccentric nucleus (mo); initial previtellogenic oocytes (ipo); final previtellogenic oocytes (fpo); atresic oocytes (ao). $(c, d)$ Ovaries in regressing phase with mature oocytes (mo); initial previtellogenic oocytes (ipo); oocytes in different stages of atresia (ao); postovulatory follicle ( $\mathrm{pfo}) .(e, f)$ Ovaries in regenerating phase with previtellogenic oocytes (po); proliferation of oogonia (og); initial previtellogenic oocytes (ipo) and cysts with prophasic oocytes (c). Abbreviations: lu: ovarian lumen; n: nucleus. Arrowhead: postovulatory follicle (pfo). Stain: haematoxylin and eosin.

Quagio-Grassiotto et al., 2011; Cassel et al., 2017a; Varela et al., 2017), as observed for D. aequipinnatus. However, for $D$. aequipinnatus, the presence of lipid droplets was not observed. This absence of lipid droplets has been reported for some marine species, including Aspitrigla obscura (Muñoz et al., 2002), Liza aurata (Shabanipour \& Heidari, 2004) and Sciaenops ocellatus (Grier, 2012).

The morphology of the $D$. aequipinnatus postovulatory follicles is similar to that described in the literature, being a remaining structure of the theca layer, follicular 
cells and basement membrane (Amorim, 2007; QuagioGrassiotto et al., 2013) when mature oocytes were ovulated during the reproductive cycle (Morais et al., 2016).

The atresic oocytes of $D$. aequipinnatus are also morphologically similar to other species, such as Danio rerio (Üçüncü \& Çakici, 2009), Prochilodus argenteus (Santos et al., 2008), Leporinus taeniatus (Thomé et al., 2012) and Astyanax altiparanae (Cassel et al., 2017b). For D. aequipinnatus, observation of the atresia process was most commonly seen in oocytes at a more advanced stage of development, such as vitellogenesis (Üçüncü \& Çakici, 2009).

Based on the methodology proposed by BrownPeterson et al. (2011) and adapted in this study, Wildner et al. (2013), Quagio-Grassiotto et al. (2013) and Santos-Silva et al. (2015) also described the same reproductive phases for other orders, such as Siluriformes, Characiformes and Labriformes. Although this standardization has been developed for marine fish, this nomenclature has also proven to be appropriate for other species. However, for D. aequipinnatus, it was necessary to adapt the development phase to achieve a better understanding of the reproductive dynamics.

Thus, changes in the nuclear, cytoplasmic and follicular proportions arise as a result of an important underlying processes. These findings highlight the importance of studies addressing oocyte development to advance the understanding of reproduction (Marques et al., 2000). Thus, the cell modifications that occur between folliculogenesis and oogenesis are an important and understudied aspect of the reproductive biology of $D$. aequipinnatus. The favourable zootechnical characteristics of D. aequipinnatus make it a suitable biological model for another studies.

\section{Acknowledgements}

We would like to thank the Fundação de Amparo à Pesquisa do Estado de São Paulo (FAPESP) (process no. 2014/12584-0) for financial support and to the Laboratório de Ictiologia Neotropical (LINEO), Universidade Estadual Paulista 'Júlio de Mesquita Filho' UNESP. We would like thank Raphael da Silva Costa for providing photographs of animals.

\section{References}

Abascal, F. \& Medina, A. (2005). Ultrastructure of oogenesis in the bluefin tuna, Thunnus thynnus. J. Morphol, 264, 14960.

Amorim, J.P.A. (2007). Foliculogênese e caracterização celular das classes reprodutivas em Pimelodus maculatus (Siluriformes: Pimelodidae). [Dissertation]. Botucatu, Universidade Estadual Paulista.
Andrade, R.F., Bazzoli, N., Rizzo, E. \& Sato, Y. (2001). Continuous gametogenesis in the neotropical freshwater teleost, Bryconops affinis (Pisces: Characidae). Tissue Cell 5, 524-32.

Arunachalam, M., Manickam, R., Manickam, C., Malaiammal, P. \& Mayden, R. (2013). Natural history of zebrafish (Danio rerio) in India. Zebrafish 1, 1-14.

Brown-Peterson, N.J., Wyanski, D.M., Saborido-Rey, F., Macewicz, B.J. \& Lowerre-Barbieri, S.K. (2011). A standardized terminology for describing reproductive development in fishes. Mar. Coast. Fish. 3, 52-70.

Cassel, M., Camargo, M.P., Jesus, L.W.O. \& Borella, M.I. (2017a). Involution processes of follicular atresia and postovulatory complex in a characid fish ovary: a study of apoptosis and autophagy pathways. J. Mol. Histol. 98, 24357.

Cassel, M., Chehade, C., Souza, G.B., Caneppele, D., Romagosa, E. \& Borella, M. (2017b). Ovarian development and the reproductive profile of Astyanax altiparanae (Teleostei, Characidae) over one year: applications in fish farming. Theriogenology 98, 1-15.

Çakici, Ö. \& Üçüncü, S.İ. (2007). Oocyte development in the zebrafish, Danio rerio (Teleostei: Cyprinidae). Eur. J. Fish Aquat. Sci. 1-2, 137-41.

Çek, S., Bromage, N., Randall, C. \& Rana, K. (2001). Oogenesis, hepatosomatic and gonadosomatic indexes, and sex ratio in Rosy Barb (Puntius conchonius). Turk. J. Fish. Aquat. Sci. 1, 33-41.

Celius, T. \& Walther, B.T. (1998). Oogenesis in Atlantic salmon (Salmo salar L.) occurs by zonagenesis preceding vitellogenesis in vivo and in vitro. J. Endocrinol. 158, 259-66.

Connolly, M.H., Dutkosky, R.M., Heah, T.P., Sayker, G.S. \& Henry, T.B. (2014). Temporal dynamics of oocyte growth and vitellogenin gene expression in zebrafish (Danio rerio). Zebrafish 11, 107-14.

Eschmeyer, W. \& Fong, J. (2017). Catalog of Fishes. Available at: http: / / researcharchive.calacademy.org/research/ ichthyology/catalog/SpeciesByFamily.asp. Accessed 28 January 2017.

Fu, C.Z., Wu, J.H., Chen, J.K., Qu, Q.H. \& Lei, G.C. (2003). Freshwater fish diversity in the Yangtze River basin in China: patterns, threats and conservation. Biodivers. Conserv. 12, 1649-85.

Ganeco, L.N., Nakaghi, L.S.O., Urbinati, E.C., Neto, R.D. \& Vasques, S.L.H. (2001). Análise morfológica do desenvolvimento ovocitário de pirancajuba, Brycon orbignyanus, durante o ciclo reprodutivo. Boletim do Instituto de Pesca 2, 131-8.

Glasser, F., Cauty, C., Mourot, B. \& Breton, B. (2003). Disrupted sexual cycles in female grass carp (Ctenopharyngodon idella) raised in tropical conditions. Aquaculture 220, 85768.

Gonçalves, T.L., Bazzoli, N. \& Brito, M.F.G. (2006). Gametogenesis and reproduction of the matrinxã Brycon orthotaenia (GÜNTHER, 1864) (PISCES: CHARACIDAE) in the São Francisco River, Minas Gerais, Brazil. Brazil. J. Biol. 66, 513-22.

Grier, H.J. (2000). Ovarian germinal epithelium and folliculogenesis in the common snook Centropomus undecimalis (Teleostei: Centropomidae). J. Morphol. 243, 265-81. 
Grier, H.J. (2012) Development of the follicle complex and oocyte staging in red drum, Sciaenops ocellatus Linnaeus, 1776 (Perciformes, Sciaenidae). J Morphol. 273, 801-29.

Grier, H.J., Uribe-Aranzabal, M.C. \& Parenti, L.R. (2007). Germinal epithelium, folliculogenesis, and postovulatory follicles in ovaries of rainbow trout, Oncorhynchus mykiss (Walbaum, 1792) (Teleostei, Protacanthopterygii, Salmoniformes). J. Morphol. 268, 293-310.

Honji, R.M., Vaz-dos-Santos, A.M. \& Rossi-Wongtschowski, C.L.D.B. (2006). Identification of the stages of ovary maturation of the Argentine hake Merluccius hubbisi Marini, 1933 (Teleostei: Merlucciidae): advantages and disadvantages of the use of the macroscopic and microscopic scales. Neotrop. Ichthyol. 3, 329-37.

Lele, Z. \& Krone, P.H. (1996). The zebrafish as a model system in developmental, toxicological and transgenic research. Biotechnol. Adv. 1, 57-72.

Lima, R.V.A., Bernardino, G., Val-Sella, M.V., Fava-deMoraes, F., Schemy, R.A. \& Borella, M.I. (1991). Tecido germinativo ovariano e ciclo reprodutivo de pacus (Piaractus mesopotamicus HOLMBERG, 1887) mantidos em cativeiro. Boletim técnico Cepta. 1, 1-46.

Marques, D.K. S., Rosa, I.L. \& Gurgel, H.C.B. (2000). Descrição histológica de gônadas de traíra Hoplias malabaricus (Bloch) (Osteichthyes, Erythrinidae) da barragem do rio Gramame, Alhandra, Paraíba, Brasil. Revista Brasileira de Zoologia. 3, 573-82.

Martins, Y.S., Moura, D.F., Santos, G.B., Rizzo, E. \& Bazzoli, N. (2010). Comparative folliculogenesis and spermatogenesis of four teleost fish from a reservoir in south-eastern Brazil. Acta Zool. 91, 466-73.

Mazzoni, T.S., Grier, H.J. \& Quagio-Grassiotto, I. (2010). Germline cysts and the formation of the germinal epithelium during female morphogenesis in Cyprinus carpio (Teleostei: Ostariophysi: Cypriniformes). Anat. Rec. 293, 1581-606.

Mayden, R.L. (1991). New World Cyprinids. In Biology of Cyprinids (eds I.J. Winfield \& J.S. Nelson), pp. 240-63. London: Chapman and Hall Ltd.

Morais, R.D.V.S., Thomé, R.G., Santos, H.B., Bazzoli, N. \& Rizzo, E. (2016). Relationship between bcl-2, bax, beclin-1, and cathepsin-D proteins during postovulatory follicular regression in fish ovary. Theriogenology 85, 1118-31.

Muñoz, M., Sabat, M., Mallol, S. \& Casadevall, M. (2002). Gonadal structure and gametogenesis of Triglia lyra (Pisces: Triglidae). Zool. Stud. 41, 412-20.

Nelson, J.S. (1994). Fishes of the World, 3rd edn. New York: John Wiley and Sons, Inc., $624 \mathrm{pp}$.

Nelson, J.S. (2006). Fishes of the World. Hoboken: John Wiley, $601 \mathrm{pp}$.

Ohta, T., Iwamatsu, M., Tanaka, Y. \& Yoshimoto, Y. (1990). Cortical alveolus breakdown in the eggs of the freshwater teleost Rhodeus ocellatus ocellatus. Anat. Rec. 4, 486-96.

Patiño, R. \& Sullivan, C.V. (2002). Ovarian follicle growth, maturation, and ovulation in teleost fish. Fish Physiol. Biochem. 26, 57-70.

Quagio-Grassiotto, I., Grier, H., Mazzoni, T.S., Nobrega, R.H. \& Amorim, J.P.A. (2011). Activity of the ovarian germinal epithelium in the freshwater cattfish, Pimelodus maculatus (Teleostei: Ostariophysi: Siluriformes): germline cysts, follicle formation and oocyte development. J. Morphol. 272, 1290-306.

Quagio-Grassiotto, I., Wilder, D.D. \& Ishiba, R. (2013). Gametogênese de peixes: aspectos relevantes para o manejo reprodutivo. Revista Brasileira de Reprodução Animal 2, 181-91.

Quagio-Grassiotto, I., Wildner, D.D. \& Guimarães-Bassoli, A.C.D. (2014). A cytochemical approach to describe oocyte development in the freshwater ostariophysan, Serrasalmus maculatus (Characiformes). Micron 60, 18-28.

Rodrigues, L.P., Querol, E. \& Braccini, M.C. (2005). Descrição morfo-histológica do ovário de Acestrorhynchus pantaneiro (Menezes, 1992) (Teleostei, Characidae), em seus diferentes estádios de desenvolvimento, na bacia do rio Uruguai médio, Uruguaiana, RS. Biodiversidade Pampeana 3, 11-8.

Santos, H.B., Thomé, R.G., Arantes, F.P., Sato, Y., Bazzoli, N. \& Rizzo, E. (2008). Ovarian follicular atresia is mediated by heterophagy, autophagy, and apoptosis in Prochilodus argenteus and Leporinus taeniatus (Teleostei: Characiformes). Theriogenology 70, 1449-60.

Santos-Silva, A., Siqueira-Silva, D., Silveira-Ninhaus, A. \& Silveira-Veríssimo, R. (2015). Oogenesis in Laetacara araguaiae (Ottoni and Costa, 2009) (Labriformes: Cichlidae). Zygote 24, 1-9.

Selman, K. \& Wallace, R.A. (1989). Cellular aspects of oocyte growth in teleosts. Zool. Sci. 6, 211-31.

Shabanipour, N. \& Heidari, B. (2004). A histological study of the zona radiata during late oocyte developmental stages in the Caspian sea Mugilid, Liza aurata (Risso, 1810). Braz. J. Morphol. Sci. 21, 37.

Shabanipour, N. \& Hossayni, S.N. (2010). Histological and ultrastructural study of zona radiata in oocyte of common carp Cyprinus carpio (Linnaeus 1758). Micron 41. 877-81.

Thomé, R.G., Domingos, F.F.T., Santos, H.B., Martinelli, P.M., Sato, Y., Rizzo, E. \& Bazzoli, N. (2012). Apoptosis, cell proliferation and vitellogenesis during the folliculogenesis and follicular growth in teleost fish. Tissue Cell 44, 54-62.

Tyler, C.R. \& Sumpter, J.P. (1996). Oocyte growth and development in teleosts. Rev. Fish Biol. Fish. 6, 287-318.

Üçüncü, S.I. \& Çakici, Ö. (2009). Atresia and apoptosis in preovulatory follicles in the ovary of Danio rerio (zebrafish). Turk. J. Fish. Aquat. Sci. 9, 215-21.

Varela, M.L., Ferreira, M.F., Da Cuna, R.H., Lo Nostro, F.L., Genovese, G. \& Meijide, F.J. (2017). Dynamics of ovarian maturation throughout the reproductive cycle of the Neotropical cichlid fish Cichlasoma dimerus (Teleostei, Cichliformes). Can. J. Zool. 95, 485-98.

Wallace, R.A. \& Selman, K. (1981). Cellular and dynamic aspects of oocyte growth in teleosts. Am. Zool. 2, 325-43.

West, G. (1990). Methods of assessing ovarian development in fishes: a review. Mar. Freshw. Res. 41, 199-222.

Wildner, D.D., Grier, H.J. \& Quagio-Grassiotto, I. (2013). Female germ cell renewal during the annual reproductive cycle in Ostariophysians fish. Theriogenology 79, 709-24.

Yön, N.D.K., Aytekin, Y. \& Yuce, R. (2008). Ovary maturation stages and histologycal investigation of ovary of zebrafish (Danio rerio). Brazil. Arch. Biol. Technol. 3, 513-22. 